\title{
Symbolism Of Javanese Culture
}

\author{
Tasrif Syam \\ College Student Doctorate Program of Development Studies \\ Faculty of Social and Political Sciences North Sumatera University \\ Medan, Indonesia \\ Email: tasrifsyam1@gmail.com
}

\begin{abstract}
A study on the traditional of Javanese people in Tanjung Morawa, especially on the ceremony that deals with the circle life of human such as mitoni ritual. This kind of ritual shows many kinds of symbols which represent the effort to preserve the Javanese culture. This research is to find out the meanings of the symbols which relate to the mitoni ritual. By understanding the meanings of symbols in mitoni ritual we will find out the way they preserving their culture. The mitoni ritual has been held since ancient time by the parents and the ancestor of Javanese people. This research study the whole ceremony consist of several steps of ritual, such as holy bathing (siraman), dressing-up of the would bemother, brojolan (coconut cracking to guess the gender of the baby), etc and the symbolic function in preserving Javanese culture.By using the data collecting and analyzing method which is including observation, interview, and data analyzing, the analyzing was done qualitative and to get the valid data the researcher used the triangular technique on the sources.The result of the research which had been analized shows that the mitoni ritual in Tanjung Morawa is one tradition which is held sustainly and become preserving until now, its all because of the simplicity of this tradition. The meanings in symbols of mitoni ritual can be depicted through symbolic by the sources though not maximum. With the meanings in those symbols, symbolic function of mitoni ritual become the glue for the togetherness of the people in Tanjung Morawa.
\end{abstract}

Keywords: symbol; mitoni ritual and preserving the Javanese culture

\section{INTRODUCTION}

As an ethnic, the traditions and actions of Javanese people always hold two things. First, the philosophy of his/her religious and mystical life, and secondly, the life ethic that upholds family's moral and dignity. The view of life always connects everything with the all-powerful Almighty, mystical, magical, with respect for the spirits of ancestors, ancestors and invisible supernatural powers by human senses. Therefore, the Javanese use symbols in their cultural life and customs.

The use of symbols has been done periodically and still exists nowadays. The symbol used by Javanese people in general shows their life. Since their life up to death is cannot be freed by the symbols. For example, when Javanese girl whose pregnancy age in seven-month, mitoni's ritual is carried out with the meaningful symbols. Mitoni's ritual was a traditional Javanese schedule existed and preserved in Deli, especially Tanjung Morawa which upholds symbolic value and various meaning from its preparation up to its implementation.

Endraswara [1] states that seven-month limitation is actually a characteristic symbol that couple affair is not carried out so that the baby will be in a good process. Mitoni's ritual consists of some symbols that seems meaningful when an assisted tool used firmly like green coconut leaf, water, egg, an earthen pot, and another equipment. It can be seen from the action done by himself/ herself, it's mean that it is a core of culture and the sign of human's action.

For Javanese (Deli) who lived in Tanjung Morawa, Mitoni's activity is a custom which has been carried out periodically. Three-quarter citizens in this area were Javanese (Deli) who uphold this ritual without omitting its Javanese feature. Did they understand the meaning over this ritual or not, it's not a problem because every ritual always guided by Javanese elder who knew its meaning. This phenomena rose and progress towards Javanese people in Tanjung Morawa. Even this mitoni tends to a tradition, it is gradually became modern because itsactivitiy is always followed by entertainment and ritual's facility which follow the modern way like bathing ritual, visual aid, and services to the guests. This research finds mitoni's ritual profoundly even from its ritual, the meanings delivered through symbols or reflection from the meaning of the ritual towards culture preservation effort in Javanese people. 


\section{THEORETICAL ANALYSIS}

\section{A. Culture and Symbol}

Tjong Geertz [2] views culture as a meaningful symbolic system, one symbol cannot be understood without any other symbols. He sees culture as the systems of meaning and the arena of each system in the culture can be used to interpret and understand the other systems of meaning in the culture concerned. Culture as a study or analytical tool consists of interrelated elements, the relationship of one to another in an integral unit, operates or moves in a system. The concept of this culture is understood as a systemic, meaning that refers to the individual, social and cultural aspects of human life as an element that has the function of guidance and energy on a reciprocal basis [3].

According to Cassirer [4] culture can be interpreted as an inseparable meaning in the symbols associated with human existence. In other words, culture is a human effort to understand himself and to overcome his problems through the creation of common sense and the use of symbols. Humans are animalsymbolic, human symbols are revealed through mite, religion, language, art, history and science. While according to Charon [5] that symbols are one class of social objects. Some social objects are symbols, some are not. Like all social objects used present, whatever people agree they shall represent.

It is very difficult to define social objects that are symbols or not. However, Herbert Blumer argues that all social objects are symbols, in which each object represents all actions we will take on the object. Blumer introduced symbolism by creating symbolic interaction terms. Through his paper entitles society as symbolic interaction, Blumer states that symbolic interaction refers to interaction of distinctive and special characters among humans. The specifics consist of the fact that humans interpret or define other human actions in response to the actions of others. In the view of symbolic interaction, the social process in the group creates and upholds life in groups.

\section{B. $\quad$ Mitoni's Ritual}

Koentjaraningrat [6] states that salvation (selametan) ritual which is non-religious rituals are ritual that do not evoke religious emotion to whom perform the selametan, nor the people who come, although someone has been asked to come at the event as religious official to recite the prayer. So the purpose of selametan like this is just to maintain a sense of social solidarity and to create a peaceful atmosphere, free of hostility and prejudice against others, or it can also be a celebration of a happiness event.

The image of gestation is described as ninestages according to gestational age. One-month pregnancy is called ekakamandanu, it means that the pregnant is due to the fruit of love between husband and wife. The two-month-old pregnancy is called dwi-panunggal, it means to unify the love between husband and wife. Tri lokamaya is a third month gestational age defined between pregnant and not, and the fourth month of pregnancy imaged with caturhangga jati, defined as forming the body. When the fifth month of pregnancy is called pancayitmajati, and the sixth month is called sad loka jati, the more complete the baby's organs, and the seven-month pregnancy is imaged with saptakawasajati, if it is natural that this baby may be born healthy. While the eighth month of gestation is called hasthasabda jati, and the ninth month of pregnancy is called nawapurna jati, the presence of a baby.

The mitoni ritual or seven-month is a salvation for a woman's pregnancy as a fully seven months. This is filled with symbolic acts intended to allow the fetus to meet the its parents' expectations of and be born through a simple process and safety. Similarly, some of the taboos that must be obeyed by the wife and her husband in order to maintain the safety of the birth of her baby. How the Javanese people can maintain this traditionally hereditary custom is the unofficial agreement between them, at least Parson in Ritzer and Goodman [7] states that in order to survive, a system must have four functions, namely; adaptation, goal attainment, integration and latency (maintenance).

\section{RESEARCH METHOD}

This research employs descriptive symbolic analysis and qualitative. The object of this research is more focused on the Javanese community who resides around Tanjung Morawa Subdistrict, Deli Serdang Regency, which are dominated by many Javanese ethnic. This study also looks at how the mitoni ritual is carried out in a hierarchical manner and the meaning of symbols attached to the ritual as well.

To collect the data, the researcher conducted observations and in-depth interviews so that the information could be gained perfectly, and the target of the source was the Javanese community leaders in rolling to other sources, or the snowball-approach model. This model is carried out continuously against community leaders or Javanese customs. 
In order to obtain the accuracy of the data, researcher adjusts the data obtained with the concept of research. Then to get the validity of the data, triangulation technique with the source is implemented, that is to compare the observation data with interview data, or to compare the results of interviews with the contents of an interrelated document.

This study focuses on the direct observation of how the mitoni's ritual is carried out systematically and the meanings of symbolism attached to the ritual, as well as the understanding of Javanese society towards the meaning of the symbols as an effort to preserve Javanese culture. To produce accurate data about the meaning of the symbols of the ritual, it involves several speakers from Javanese leaders or elders who deeply understand Java ${ }^{B}$. mitoniritual. The intended speakers are some people who have been accustomed to be a guide at the mitoni's ritual and other Javanese traditional events.

\section{RESEARCH DISCUSSION}

\section{A. The Existence of Mitoni's Ritual on Javanese People}

In general, Javanese people who live in Tanjung Morawa sub district tend to maintain their traditional order, although sometimes less understanding all the meaning of the contents of the tradition. So far they have always been traced to the old man's speech or the instructions of parents who inherited their traditions, and it is a duty that must be done to preserve their culture outside of Java. Their unfamiliarity with the meanings of the symbols of tradition or custom held tends to be unidirectional. That is, not only in a custom of marriage for example, but also in some other habits they do not understand the meaning behind the tradition, although some of them know its meaning.

Similarly, on the term mitoni. Terms that are derived from syllables, such as mitoni or tingkeban are less familiar in their ears. The original Javanese language is better known among Javanese community in Tanjung Morawa District with the term seventh month (nujubulan) prenatal ceremony. This mitoni or seven-month ritual is more sociable than other traditions such as down to earth (tedaksinten), because all the families and the surrounding community can rejoice with the presence of a prospective mother who will perform the birth process. This ritual always follow the tradition that has been inherited by the ancestors and their parents, even this ritual is already solidified by the Javanese people who have lived long time ago in Tanjung
Morawa District. They tend to perform this ritual even they did not understand meaning precisely because this habit becomes maintained and sustainable thing.

The ritual is also considered to be simpler than the marriage ritual. The simplicity arose when siraman event was done at the place where it can be enjoyed by the family as a companion. Couples are directly involved in an event, and they are inseparable, as well as when this part of the ritual is made that is jualdawet, all people can enjoy the show with simplicity and kinship. This ritual is a good news to the family and the public, that the woman who is pregnant has entered the seventh age of her pregnancy, it means that a few months later, she will become a mother.

\section{The Symbolism of Bathing Event}

This event is symbolically interpreted as a picture that the birth of a baby becomes pure and clean. Number seven is related to the sevenmonth pregnancy age that comes from the Java language pitu, which means pitulungan or help. Hopefully, the baby born will get help from the Almighty. Similarly, the water spray is considered sacred namely sekarsetaman water. This sacred water is taken from seven water wells or seven springs which are then bathed to the expectant mother in the hope of obtaining cleanliness for the contents of mother and baby, in line with the fragrant flowers mixed into the water, for example, cantilever flowers, roses, cananga, and palm plant.

The process of bathing for the prospective mother is carried out in a place called krobongan. Krobongan is the symbol of the world, that the pregnant woman and her partner in childbirth will later be painted into a forest (pasren), and the door of krobongan ideally to the east. The eastern direction is the embodiment of Javanese language wetan (wiwitan), which means that the east is early of a life. Husband and her wife are ready to face the beginning of life after getting a baby.

The end of the siraman event is marked by the wearing of cloth with the fabric tied by letrek. The term letrek means a kind of thread consisting of three colors, namely red, white and black. The red color symbolically means the love of mother, white means the sense of responsibility of the father's candidate, and the black is the power of the Almighty who unites the love of both parents. Although the siraman event in some Javanese people are varied, but the essence of the meaning of symbolism that led to the birth process to be saved. 


\section{The Symbolism of Cloth Replacement}

Clothing changed in seven times at the second stage of this mitoni's ritual is batik cloth not the whole clothing. Batik cloth is believed by ${ }_{E}$ Javanese ancestors as a great dress for the former Javanese kings, and this belief inherits the Javanese society up to nowadays. Batik cloth better known by Javanese people is batik sidamukti, which means the origin of Javanese language means the desire to get nobility for the family and their children.

At the seventh turn, batik cloth worn on the prospective mother, tied up with Tebu Tulak (black and white) or replaced with white thread that will be cut by the husband at the event. Tebu Tulak is symbolically defined as a symbol to deny the danger that the child born will be spared from obstacles, while the white thread known as lawe as an opened symbol of the birth node, puser or placenta of the baby. Birth obstacle is considered dangerous that has already passed by the husband by slashing the cloth with a dagger, so the baby will be born easily and saved. Dagger in Javanese is kacurigan, for Javanese, dagger seats identically to batik cloth as a great inheritance by their ancestors since the time of the kingdom, even in the development of Hindu religion / culture in Java.

\section{The Symbolism of Brojolan Event}

The third part of the mitoni's ritual is known as brojolan. This section shows the symbolic interaction between families, from the prosperous mother, the grandmother until the $F$. husband played directly and simultaneously and resulted in the meaning behind the action. The visual aid in this event is ivory coconut raised by the husband, then in the break into the cloth that his wife used toward the belly down. Coconut will roll down and greeted by the grandmother and so on trying to carry the ivory coconut in her hands.

The coconut used as a visual aid is ideally showed a picture of some puppet figures. Picture or painting of this figure is only a visualization of the Javanese prayer for the birth of the baby later if the male or female bias dashing and as beautiful as the figures described earlier. Javanese relationship with puppet is a good person's relationship in seeking good merit because the story of puppet contains universal moral element.

Initially this brojolan process is likened to guess about the sex for the baby born. Although there are now sophisticated medical devices to look at the sexes, this section does not diminish the significance of the families who conducts the ritual. The goal of this event is not the true truth to the sex of the baby's candidate, but more than just appreciates the process of this event that can be perfectly understood.

\section{The Symbolism of Feast Event}

The end of the mitoni's ritual is a feast. This event is to maintain solidarity among the guests of the law, and in order to maintain good relationships with local people who are inwardly familiar with the existence of the families who conduct this ritual. This event is known as the selling dhawet and rujak which is done in the front yard of the house by the simple means. Payer tool is in the form of artificial money known as kreweng or fractional tile. The symbol of the tile means as a protector for the house and family who live in. Furthermore, the money is entered into a soil pan, and the process of this activity can be interpreted so that baby born will get sustenance.

To entrust the event, this feast is included with offerings or ubarampe prepared as a simple dish. The offerings are diverse, includes seven tumpeng and one of them is larger than the other six tumpeng. Another offer is sticky rice procot, sticky rice mixed with coconut milk and put in banana leaves. Javanese people here more often use the term buburprocot rather than sticky rice, because the ingredients of rice flour and shaped like a porridge in the middle placed plantain. It is intended that later on in the birth process is not too difficult so that the mother did not feel very much pain.

\section{The Symbolism of Javanese Culture Preservation}

It is symbolized as a system, then the mitoni's ritual can be viewed as a social system that is structured so that it can function harmoniously. The preservation of the tradition of mitoni's ritual precisely because the series of hierarchy event that is occurred in the ritual. This ritual does not only perform in one particular attraction, such as the splash event, but also performs other attraction that is systemically interrelated. The relationship between holy bathing, clothing change, brojolan and feast in the mitoni's ritual becomes an attraction for the surrounding community, both as entertainment and maintaining their customs.

The mitoni's ritual can fulfill the actors' needs in significant proportions. Symbolically, the series of events involved many people who donot only joined in the in-group (family), but also played from the out-group (guests). Thus, mitoni's ritual preserves Javanese culture that can portray various parties in a system (ritual). 
The mitoni's ritual can be preserved in Javanese culture whereas symbolically as a function of adaptation. Compared to other types of tradition in Javanese society, mitoni is more sociable because the simplicity of the show which is relatively easy to implement. In visual aid, it can be found in the community, as well as the process of the show. This ritual also symbolically plays a role in carrying out moral functions. Pregnant women according to Javanese tradition must run some ban or taboo, namely the prohibition related to the moral of the prospective mother and her husband. This prohibition also serves as an effort to maintain health for prospective mothers and become a motivation among the people of Java. The participative level of society will increase with ${ }^{1]}$ this ritual, especially in the event of helping to help them.

\section{CONCLUSION}

The mitoni's ritual can survive and become a sustainable tradition in Tanjung Morawa sub ${ }^{[4]}$ district because the view of Javanese society of this ritual has a simpler value from its rules[5] when it is compared with other Javanese tradition and ceremonies. The nature of simplicity is not only in the series of activities, but also on the facilities used as a tool that is not7] luxurious and expensive.
Sevent month or nujubulan is more popular and social than mitoni's term or tingkeban, although the procedure of execution remains the same as the usual. In essence, the mitoni's ritual is symbolic in meaning which is the hope for the smooth process of the birth of a baby that can be done easily, smooth and healthy. Conceptually, this ritual is an indicator of the many ceremonies in Javanese custom which can be sustainable, so that the ritual becomes an enduring part of Javanese cultural values. A series of meanings that can be extracted in this ritual,are not found in the same habits as other ethnic customs.

\section{REFERENCES}

S. Endaswara, "Budi Pekerti dalam Budaya Jawa," Yogyakarta: Hanindita, 2003

C. Geertz, "The Interpretation of Culture," New York: Basic Book, 1973

P. Suparlan, "Antropologi untuk Indonesia: Membangun Martabat Manusia," Yogyakarta: Gajah Mada Pers, 1992

E. Cassirer, " Manusia dan Kebudayaan: Sebuah Essay tentang Manusia," Jakarta: Gramedia, 1981

M. J. Charon, "Symbolic Interactionism: An Introduction, An Interpretation, An Intregation," Englewood Cliffs N.J : Prentice-Hall, Inc, 1979

Koentjaraningrat, "Kebudayaan Jawa," Jakarta: Balai Pustaka, 1984

G. Ritzer and J. Goodman, "Teori Sosiologi Modern," Jakarta" Prenada Media, 2004 